\title{
Evaluation of the use of lignite of Turkeys' with biomass as Agricultural waste as fuel in terms of emissions
}

\author{
Okan $\mathrm{Kon}^{1}$ and $\dot{I}_{\text {smail Caner, }}{ }^{2 *}$ \\ ${ }^{1}$ Balikesir University, Engineering Faculty, Department of Mechanical Engineering, \\ Cagis Campus, 10145 Balikesir, Turkey \\ ${ }^{2}$ Balikesir University, Engineering Faculty, Department of Mechanical Engineering, \\ Cagis Campus, 10145 Balikesir, Turkey
}

\begin{abstract}
Agricultural wastes as Biomass contains low carbon, high hydrogen, high oxygen and a lower amount of sulfur. Coals contain higher amounts of carbon, lower amounts of hydrogen, lower oxygen and higher amounts of sulfur. With the use of lignite and biomass mixture as fuel will provide less $\mathrm{CO}_{2}$ and $\mathrm{SO}_{2}$ emissions and a more economical mixture will be obtained. Considering these emissions, fluidized bed combustion systems are recommended in the literature for the combustion of lignite and biomass. In this study, rice husks, corn cobs, walnut shells, sunflower shells, olive cake and woodchips were used as agricultural waste. 10 different lignite extracted from Turkey were used as fuel. It has been assumed that the combustion process was carried out by taking the biomass rate of $10 \%, 30 \%$ and $50 \%$. When burning of 1 $\mathrm{kg}$ of lignite and biomass mixture, the highest $\mathrm{CO}_{2}$ emission occurs from $10 \%$ woodchips - $90 \%$ Kütahya Ömerler (washed) mixture as $2.938 \mathrm{~kg}$ and the highest $\mathrm{SO}_{2}$ emission obtained from $10 \%$ olive cake - 90\% Kütahya Seyitömer-Ayvalı lignite mixture as $0.061 \mathrm{~kg}$. The highest $\mathrm{H}_{2} \mathrm{O}$ emission was obtained by mixing $50 \%$ woodchips - $50 \%$ Manisa-Kisrakdere lignite as $0.563 \mathrm{~kg}$.
\end{abstract}

\section{Introduction}

Most of the energy needs that increase with population and industrialization are met from fossil fuels. Environmental pollution caused by the production and use of energy from fossil fuels and the limited reserves of fossil resources is the most important problems encountered today. Today, it is important for energy policies to develop appropriate technologies for the utilization of low-quality lignite. Biomass is a renewable fuel type and its pollutant properties are low compared to coal. In Turkey, which is an agricultural country, biomass, one of the renewable energy sources, has a wide usage potential. Combustion of coal and biomass by mixing, economical use of low-quality coal and biomass are important in terms of reducing the consumption of both produced pollutants and fossil fuels. It is necessary to examine the combustion behaviour of coal biomass mixtures of these systems. Thus, biomass and coal have different burning behaviours due to their chemical composition. The combination of fossil fuels such as coal and biomass creates an opportunity for the development of new technologies and a great economic contribution [1, 2].

A. Elorf and B. Sarh examined the effect of $\lambda=1.3$, 1.7, 2.3, and 2.7 different excess air ratios on the pulverized olive cake (OC) of combustion dynamics in a vertical oven [1]. D. Kopuz investigated the Tekirdag Malkara and Çorum Bayat lignites and peach kernel and cherry kernel biomasses also, the combustion behavior of their mixtures in different proportions [2]. B. Engin et al have presented experimental studies related to the combustion of 18 lignite samples obtained from various lignite fields of Turkey in a $30 \mathrm{kWth}$ circulating fluidized bed combustor [3]. L. Armestoa et al have demonstrated the importance of burning coal and foot cake together in terms of utilizing a very specific biomass waste from the olive oil industry. Two different types of coal, lignite, and anthracite, were used for the study. Flammability tests were carried out in a fluidized bed facility [4]. W. K. Kordylewski et al have researched slag reduction by mixing Polish lignite and bituminous coal with biomass as laboratory-scale preliminary. Three agricultural biomass fuels (cereal straw sunflower husk, rape straw) and olive cake were used in the experiments [5]. T. Madhiyanon et al have investigated the Combustion properties of rice husk in combination with bituminous coal, emissions of fuel mixtures, and combustion efficiency were investigated together with the $120 \mathrm{~kW}$ th cyclone fluidized-bed combustor [6]. A. T. Atimtay and M. Varol examined the combustion performances and emission characteristics of olive cake and coal mixture (Tuncbilek lignite) in bubbling fluidized bed. Burning tests were carried out with olive cake mixing ratios of $25 \%, 50 \%$, and $75 \%$ by weight [7]. S. V. Vassilev et al in their study, extensive research has done on the phasemineral transformations of organic and inorganic matter that occur during biomass combustion [8]. M. Varol et al investigated the combustion of Bursa-Orhaneli lignite and

\footnotetext{
Corresponding author: ismail@balikesir.edu.tr
} 
$10 \%, 30 \%$, and $50 \%$ wood chips mixtures with circulating fluidized bed combustor with excess air ratio varying between 1.05-2.43 [9]. M. A. Bennini et al examined the burning of raw olive pomace, exhausted olive pomace and deoiled olive pomace in a fixed bed boiler in their study [10]. A. A. Bhuiyan and J. Naser investigated the cocombustion of biomass coal mixture in a $0.5 \mathrm{MW}$ smallscale furnace under air and an oxy-fuel condition was studied. The necessary programs for chemical reactions, heat transfer, fluid and particle flow fields and turbulence calculation are coded [11]. A. Pimchuai et al investigated the torrefaction process of rice husk and mixtures of four different agricultural wastes such as sawdust, peanut husks, bagasse, and water hyacinth with lignite [12]. D. Vamvuka and S. Saxioni were examined the composition of ash produced from fixed bed combustion experiments using various urban waste and their mixtures with lignite were investigated. Slagging and fouling trends and environmental effects on recycling to soil have been studied. The effects of the combustion temperature and the percentage of biomass in the mixture were examined [13]. W. Jerzak et al examined the combustion of cedarnut hull and high sulfur lignite mixture in a fluidized bed reactor. In the study, it has been shown that burning bituminous coal with cedarnut shells under the same conditions does not show a significant decrease in SO2 emissions [14]. A. Elorf et al investigated the effect of inlet vortex motion on the flow behavior and combustion dynamics of the olive cake (OC) milled in a 3dimensional vertical furnace [15]. N. Vardar and N. İlten measured the flue gas emissions generated in the facilities where the pomace is burned in Balıkesir province, which has approximately $12-25 \%$ of the olive pomace production in Turkey and the emissions were evaluated according to the oxygen in the flue gas [16]. W. Jerzak et al investigated the combustion of nutshells and bituminous coal in a new two-disc reactor supporting two fluidized beds stacked one above the other [17].

The purpose of this study is to obtain a new lignitebiomass fuel mixture using 10 different lignites with the highest ratio of carbon which obtained from different regions of Turkey and 6 different biomass. Then the $\mathrm{CO}_{2}$, $\mathrm{SO}_{2}$ and $\mathrm{H}_{2} \mathrm{O}$ emission amounts that will occur by burning these fuel mixtures in fluidized bed boilers were calculated. The ratio of agricultural wastes used as biomass has been accepted as $10 \%, 30 \%$ and $50 \%$. The combustion process was assumed to be full combustion and air excess coefficient was 1.5.

\section{Methodology}

\subsection{Chemical formulas of fuel mixes}

The total mass of $\mathrm{K}$ mixtures $\left(\mathrm{m}_{\text {mixT }}\right)$ is the sum of the individual masses of the mixes. The total mole amount of the mixture is $\left(\mathrm{n}_{\text {mixT }}\right)$ the sum of the individual molar amounts of the mixtures [18].

$$
\mathrm{m}_{\text {mixT }}=\sum_{\mathrm{i}=1}^{\mathrm{K}} \mathrm{m}_{\mathrm{i}}
$$

$$
\mathrm{n}_{\text {mixT }}=\sum_{\mathrm{i}=1}^{\mathrm{K}} \mathrm{n}_{\mathrm{i}}
$$

The ratio of the individual molar amounts of the mixture to the molar amount of the total mixture $\left(y_{n i}\right)$ is the molar ratio.

$$
\mathrm{y}_{\mathrm{ni}}=\frac{\mathrm{n}_{\mathrm{i}}}{\mathrm{n}_{\mathrm{T}}}
$$

The ratio of the individual mass amounts of the mixture to the mass amount of the total mixture is the mass ratio $\left(\mathrm{y}_{\mathrm{mi}}\right)$ is the mass ratio.

$$
\mathrm{y}_{\mathrm{mi}}=\frac{\mathrm{m}_{\mathrm{i}}}{\mathrm{m}_{\mathrm{T}}}
$$

Sum of the mass ratio $\left(\mathrm{y}_{\mathrm{mi}}\right)$ and mole ratio $\left(\mathrm{y}_{\mathrm{ni}}\right)$ is one.

$$
\begin{aligned}
& \sum_{1}^{\mathrm{K}} \mathrm{y}_{\mathrm{m}_{\mathrm{i}}}=1 \\
& \sum_{1}^{\mathrm{K}} \mathrm{y}_{\mathrm{n}_{\mathrm{i}}}=1
\end{aligned}
$$

The molar quantity (n) is equal to the divided by the molar mass (M) of a substance mass (m) [18].

$$
\mathrm{n}=\frac{\mathrm{m}}{\mathrm{M}}
$$

\subsection{Combustion equations and emission calculation}

$$
\begin{array}{r}
\mathrm{C}_{\mathrm{a}} \mathrm{H}_{\mathrm{b}} \mathrm{O}_{\mathrm{z}} \mathrm{S}_{\mathrm{p}} \mathrm{N}_{\mathrm{q}}+\lambda \cdot \mathrm{A} \cdot\left(\mathrm{O}_{2}+3,76 \mathrm{~N}_{2}\right) \rightarrow \\
\text { a. } \mathrm{CO}_{2}+(\mathrm{b} / 2) \cdot \mathrm{H}_{2} \mathrm{O}+\text { p. } \cdot \mathrm{SO}_{2}+\text { B. } \mathrm{O}_{2}+\text { D. } \mathrm{N}_{2}
\end{array}
$$

If oxygen is balanced for $\mathrm{A}, \mathrm{B}$ and $\mathrm{D}$, the following equations are obtained. $\lambda$ is excess air ratio [19].

$$
\begin{gathered}
\mathrm{A}=\left(\mathrm{a}+\frac{\mathrm{b}}{4}+\mathrm{p}-\frac{\mathrm{z}}{2}\right) \\
\mathrm{B}=(\lambda-1) \cdot\left(\mathrm{a}+\frac{\mathrm{b}}{4}+\mathrm{p}-\frac{\mathrm{z}}{2}\right) \\
\mathrm{D}=3,76 \cdot \lambda \cdot\left(\mathrm{a}+\frac{\mathrm{b}}{4}+\mathrm{p}-\frac{\mathrm{z}}{2}\right)+\frac{\mathrm{q}}{2} \\
\mathrm{M}_{\mathrm{CO}_{2}}=\frac{\mathrm{a} \cdot \mathrm{CO}_{2}}{\dot{\mathrm{M}}}=\frac{\mathrm{a} \cdot 44}{\dot{\mathrm{M}}} \quad \mathrm{kgCO}_{2} \\
\mathrm{M}_{\mathrm{SO}_{2}}=\frac{\mathrm{p} \cdot \mathrm{SO}_{2}}{\dot{\mathrm{M}}}=\frac{\mathrm{p} \cdot 64}{\dot{\mathrm{M}}} \quad \mathrm{kgSO}_{2} \\
\mathrm{M}_{\mathrm{H} 2 \mathrm{O}}=\frac{\mathrm{b} \cdot \mathrm{H} 2 \mathrm{O}}{\dot{\mathrm{M}}}=\frac{\mathrm{b} \cdot 9}{\dot{\mathrm{M}}} \quad \mathrm{kgH}_{2} \mathrm{O}
\end{gathered}
$$




\subsection{Properties of fuels}

Table 1 shows the lignite types used in the study and chemical ratios (wt \%) of various agricultural wastes as biomass .

Table 1. The chemical content (wt $\%$ ) of different lignite and biomass $[3,7-9]$

\begin{tabular}{|c|c|c|c|c|c|}
\hline \multicolumn{6}{|c|}{ Lignite } \\
\hline \multirow[t]{2}{*}{ Fuel } & \multicolumn{5}{|c|}{ Chemical content } \\
\hline & $\mathrm{C}$ & $\mathrm{H}$ & $\mathrm{N}$ & $\mathrm{O}$ & $\mathrm{S}$ \\
\hline $\begin{array}{l}\text { Kütahya- } \\
\text { Tunçbilek } \\
\text { (washed) }\end{array}$ & 70.58 & 4.12 & 2.19 & 6.23 & 2.39 \\
\hline $\begin{array}{l}\text { Kütahya- } \\
\text { Ömerler } \\
\text { (washed) }\end{array}$ & 69.30 & 4.31 & 2.44 & 5.48 & 1.49 \\
\hline $\begin{array}{l}\text { Kütahya- } \\
\text { Seyitömer- } \\
\text { Ayvalı }\end{array}$ & 53.70 & 2.74 & 1.12 & 11.66 & 2.51 \\
\hline $\begin{array}{l}\text { Kütahya- } \\
\text { Seyitomer- } \\
\text { Höyükaltı }\end{array}$ & 56.35 & 3.24 & 1.18 & 12.63 & 2.19 \\
\hline $\begin{array}{l}\text { Kütahya- } \\
\text { Seyitömer } \\
\text { (washed) }\end{array}$ & 55.36 & 3.15 & 1.22 & 12.93 & 2.55 \\
\hline $\begin{array}{l}\text { Manisa Imbat } \\
\text { (washed) }\end{array}$ & 66.54 & 4.11 & 1.98 & 11.71 & 1.01 \\
\hline $\begin{array}{l}\text { Manisa } \\
\text { Kisrakdere }\end{array}$ & 66.55 & 4.69 & 1.06 & 13.44 & 0.79 \\
\hline $\begin{array}{l}\text { Manisa } \\
\text { Dereköy }\end{array}$ & 67.55 & 4.68 & 1.28 & 12.23 & 1.34 \\
\hline $\begin{array}{l}\text { Muğla } \\
\text { Eskihisar }\end{array}$ & 54.00 & 3.67 & 1.30 & 15.03 & 1.31 \\
\hline Bursa Orhaneli & 69.26 & 4.74 & 0.97 & 13.50 & 2.18 \\
\hline \multicolumn{6}{|c|}{ Biomass } \\
\hline Rice husks & 49.3 & 6.1 & 0.8 & 43.6 & 0.08 \\
\hline Corn cobs & 47.8 & 5.9 & 0.5 & 45.6 & 0.01 \\
\hline Walnut shells & 49.8 & 6.2 & 1.4 & 42.4 & 0.09 \\
\hline $\begin{array}{l}\text { Sunflower } \\
\text { shells }\end{array}$ & 50.4 & 5.5 & 1.1 & 42.9 & 0.03 \\
\hline olive cake & 51.4 & 5.8 & 1.3 & 36.9 & 0.08 \\
\hline Woodchips & 53.7 & 6.9 & 0.3 & 37.7 & 0.00 \\
\hline
\end{tabular}

\section{Results and Discussion}

In Figure 1, the change of $\mathrm{CO}_{2}, \mathrm{SO}_{2}$ and $\mathrm{H}_{2} \mathrm{O}$ emissions for a) rice husks b) corn cobs biomass mixed with different lignites at different rates are given. Figure 2 shows the $\mathrm{CO}_{2}, \mathrm{SO}_{2}$ and $\mathrm{H}_{2} \mathrm{O}$ emissions changes for a) walnut shells b) sunflower shells biomass mixed with different lignites at different rates. Figure 3 shows the $\mathrm{CO}_{2}, \mathrm{SO}_{2}$ and $\mathrm{H}_{2} \mathrm{O}$ emissions for a) olive cake b) woodships biomass mixed with different lignites at different rates.

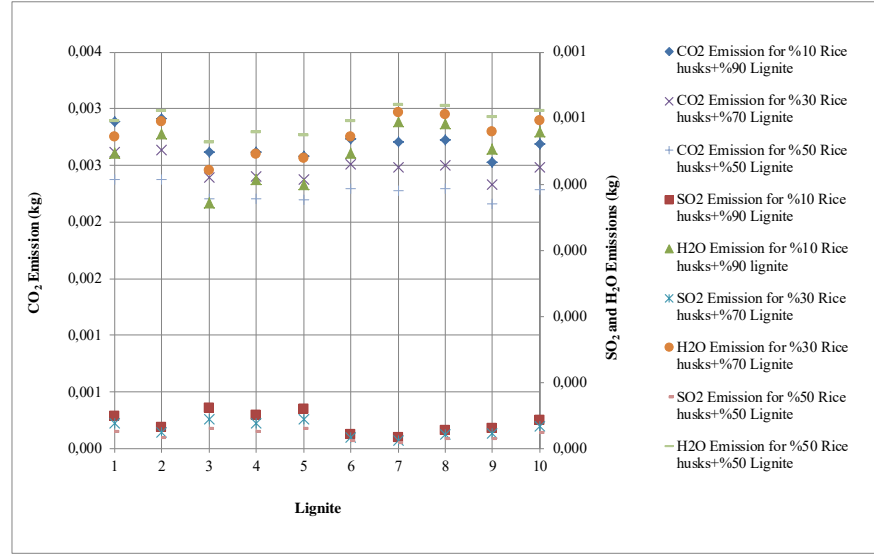

(a)

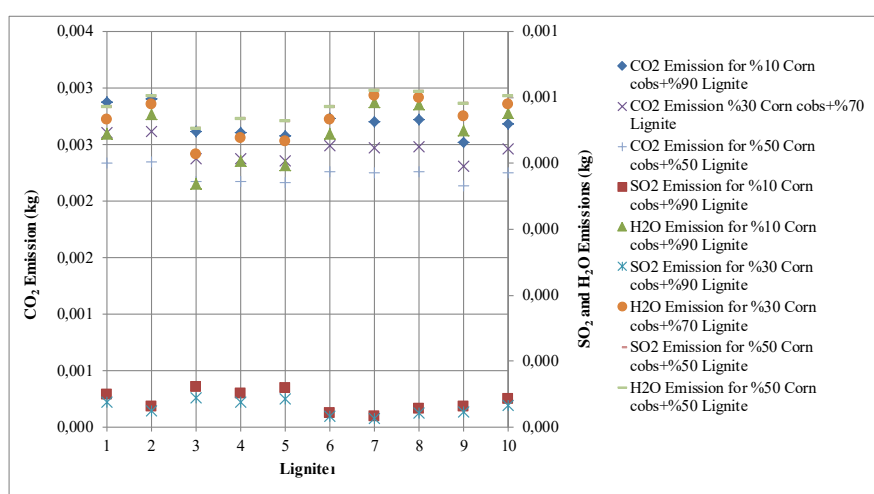

(b)

Fig. 1. The change of $\mathrm{CO}_{2}, \mathrm{SO}_{2}$ and $\mathrm{H}_{2} \mathrm{O}$ emissions for (a) rice husks (b) corn cobs biomass mixed with different lignites at different rates

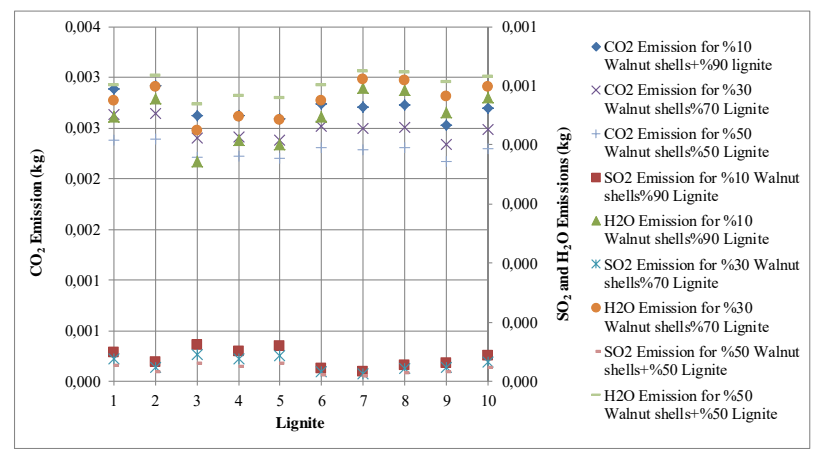

(a)

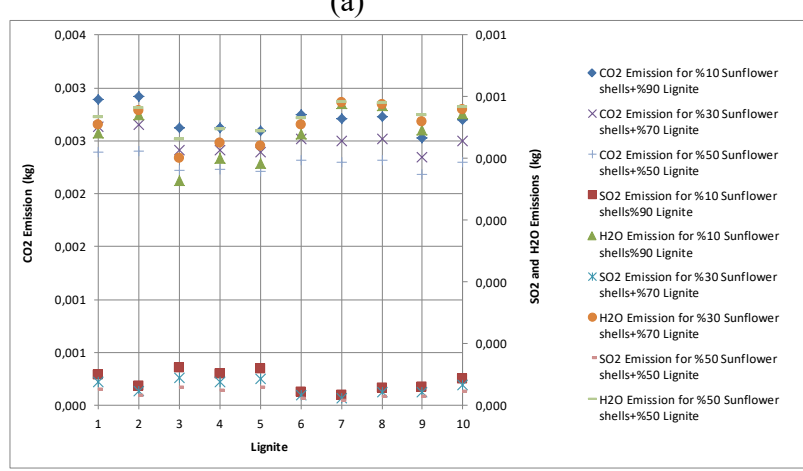

(b)

Fig. 2. The $\mathrm{CO}_{2}, \mathrm{SO}_{2}$ and $\mathrm{H}_{2} \mathrm{O}$ emissions changes for (a) walnut shells (b) sunflower shells biomass mixed with different lignites at different rates 


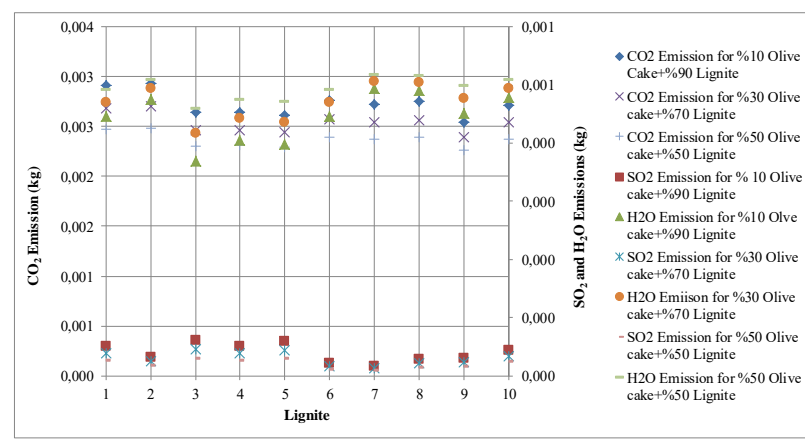

(a)

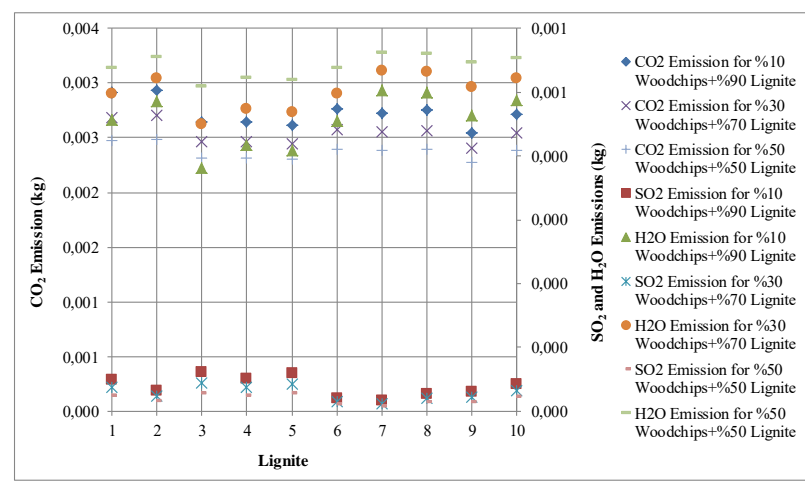

(b)

Fig. 3. The change of $\mathrm{CO}_{2}, \mathrm{SO}_{2}$ and $\mathrm{H}_{2} \mathrm{O}$ emissions for (a) olive cake (b) woodships biomass mixed with different lignites at different rates

By burning $1 \mathrm{~kg}$ of $10 \%$ rice husks and $90 \%$ lignite composition, the highest $\mathrm{CO}_{2}$ emission with $2.913 \mathrm{~kg}$ occurs in Kütahya-Ömerler (washed) and the lowest in Muğla-Eskihisar lignite with $2.524 \mathrm{~kg}$. The highest $\mathrm{SO}_{2}$ emission occurs in Kütahya Seyitömer-Ayvalı with 0.060 $\mathrm{kg}$, while the lowest occurs in Manisa Kisrakdere lignite with $0.016 \mathrm{~kg}$. The highest $\mathrm{H}_{2} \mathrm{O}$ emission is $0.495 \mathrm{~kg}$ in Manisa Kısrakdere lignite, while Kütahya SeyitömerAyvalı with the lowest $0.371 \mathrm{~kg}$ occurs. With the burning of $1 \mathrm{~kg}$ of $30 \%$ rice husks and $70 \%$ lignite composition, the highest $\mathrm{CO}_{2}$ emission with $2.635 \mathrm{~kg}$ occurs in Kütahya-Ömerler (washed) and the lowest in MuğlaEskihisar lignite with $2.332 \mathrm{~kg}$. The highest $\mathrm{SO}_{2}$ emission occurs in Kütahya Seyitömer-Ayvalı with $0.044 \mathrm{~kg}$, while the lowest occurs in Manisa Kisrakdere lignite with 0.013 $\mathrm{kg}$. With the burning of $1 \mathrm{~kg}$ of $50 \%$ rice husks and $50 \%$ lignite composition, the highest $\mathrm{CO}_{2}$ emission with 2.378 $\mathrm{kg}$ occurs in Kütahya-Ömerler (washed) and the lowest in Muğla-Eskihisar lignite with $2.162 \mathrm{~kg}$. The highest $\mathrm{SO}_{2}$ emission occurs in Kütahya Seyitömer-Ayvalı with 0.030 $\mathrm{kg}$, while the lowest in Manisa Kisrakdere lignite with $0.009 \mathrm{~kg}$. The highest $\mathrm{H}_{2} \mathrm{O}$ emission is $0.521 \mathrm{~kg}$ in Manisa Kısrakdere lignite and Kütahya Seyitömer-Ayvalı with the lowest $0.464 \mathrm{~kg}$.

By burning $1 \mathrm{~kg}$ of $10 \%$ corn cobs and $90 \%$ lignite composition, the highest $\mathrm{CO}_{2}$ emission with $2.907 \mathrm{~kg}$ occurs in Kütahya-Ömerler (washed) and the lowest in Muğla-Eskihisar lignite with $2.517 \mathrm{~kg}$. The highest $\mathrm{SO}_{2}$ emission occurs in Kütahya Seyitömer-Ayvalı with 0.061 $\mathrm{kg}$, while the lowest in Manisa Kisrakdere lignite with $0.016 \mathrm{~kg}$. The highest $\mathrm{H}_{2} \mathrm{O}$ emission occurs in the Manisa
Kısrakdere lignite with $0.493 \mathrm{~kg}$ and in Kütahya Seyitömer-Ayvalı lignite with the lowest $0.369 \mathrm{~kg}$. With the burning of $1 \mathrm{~kg}$ of $30 \%$ corn cobs and $70 \%$ lignite composition, the highest $\mathrm{CO}_{2}$ emission with $2.617 \mathrm{~kg}$ occurs in Kütahya-Ömerler (washed) and the lowest in Muğla-Eskihisar lignite with $2.313 \mathrm{~kg}$. The highest $\mathrm{SO}_{2}$ emission occurs in Kütahya Seyitömer-Ayvalı with 0.044 $\mathrm{kg}$, while the lowest occurs in Manisa Kisrakdere lignite with $0.012 \mathrm{~kg}$. The highest $\mathrm{H}_{2} \mathrm{O}$ emission is $0.502 \mathrm{~kg}$ in Manisa Kısrakdere lignite and Kütahya Seyitömer-Ayvalı with the lowest $0.414 \mathrm{~kg}$. By burning $1 \mathrm{~kg}$ of $50 \%$ corn cobs and 50\% lignite composition, the highest $\mathrm{CO}_{2}$ emission occurs in Kütahya-Ömerler (washed) with 2,348 $\mathrm{kg}$, and the lowest in Muğla-Eskihisar lignite with 2,162 $\mathrm{kg}$. The highest $\mathrm{SO}_{2}$ emission occurs in Kütahya Seyitömer-Ayvalı with $0.029 \mathrm{~kg}$, while the lowest in Manisa Kisrakdere lignite with $0.009 \mathrm{~kg}$. The highest $\mathrm{H}_{2} \mathrm{O}$ emission occurs in Manisa Kisrakdere lignite with the highest $0.521 \mathrm{~kg}$ and Kütahya Seyitömer-Ayvalı with the lowest $0.511 \mathrm{~kg}$.

With the burning of $1 \mathrm{~kg}$ of $10 \%$ walnut shells and $90 \%$ lignite composition, the highest $\mathrm{CO}_{2}$ emission with 2.915 $\mathrm{kg}$ occurs in Kütahya-Ömerler (washed) and the lowest in Muğla-Eskihisar lignite with $2.526 \mathrm{~kg}$. The highest $\mathrm{SO}_{2}$ emission occurs in Kütahya Seyitömer-Ayvalı with 0.061 $\mathrm{kg}$, while the lowest in Manisa Kisrakdere lignite with $0.016 \mathrm{~kg}$. The highest $\mathrm{H}_{2} \mathrm{O}$ emission occurs in Manisa Kisrakdere lignite with $0.496 \mathrm{~kg}$ and lowest in Kütahya Seyitömer-Ayvalı lignite with $0.373 \mathrm{~kg}$. By burning $1 \mathrm{~kg}$ of $30 \%$ walnut shells and $70 \%$ lignite composition, the highest $\mathrm{CO}_{2}$ emission with $2.641 \mathrm{~kg}$ occurs in KütahyaÖmerler (washed) and the lowest in Muğla-Eskihisar lignite with $2.339 \mathrm{~kg}$. The highest $\mathrm{SO}_{2}$ emission occurs in Kütahya Seyitömer-Ayvalı with $0.045 \mathrm{~kg}$, while the lowest in Manisa K1srakdere lignite with $0.013 \mathrm{~kg}$. The highest $\mathrm{H}_{2} \mathrm{O}$ emission occurs in Manisa Kisrakdere lignite with $0.511 \mathrm{~kg}$ and Kütahya Seyitömer-Ayvalı lignite with lowest $0.424 \mathrm{~kg}$. With the burning of $1 \mathrm{~kg}$ of $50 \%$ walnut shells and $50 \%$ lignite composition, the highest $\mathrm{CO}_{2}$ emission with $2.388 \mathrm{~kg}$ occurs in Kütahya-Ömerler (washed) and the lowest in Muğla-Eskihisar lignite with $2.172 \mathrm{~kg}$. The highest $\mathrm{SO}_{2}$ emission occurs in Kütahya Seyitömer-Ayvalı with $0.030 \mathrm{~kg}$, while the lowest in Manisa Kisrakdere lignite with $0.009 \mathrm{~kg}$. The highest $\mathrm{H}_{2} \mathrm{O}$ emission occurs in Manisa Kisrakdere lignite with the highest $0.526 \mathrm{~kg}$ and Kütahya Seyitömer-Ayvalı with the lowest $0.469 \mathrm{~kg}$.

By burning $1 \mathrm{~kg}$ of $10 \%$ sunflower shells and $90 \%$ lignite composition, the highest $\mathrm{CO}_{2}$ emission with 2.918 $\mathrm{kg}$ occurs in Kütahya-Ömerler (washed) and the lowest in Muğla-Eskihisar lignite with $2.529 \mathrm{~kg}$. The highest $\mathrm{SO}_{2}$ emission occurs in Kütahya Seyitömer-Ayvalı with 0.061 $\mathrm{kg}$, while the lowest in Manisa Kisrakdere lignite with $0.016 \mathrm{~kg}$. The highest $\mathrm{H}_{2} \mathrm{O}$ emission occurs in Manisa Kisrakdere lignite with $0.489 \mathrm{~kg}$ and Kütahya SeyitömerAyvalı lignite with the lowest $0.364 \mathrm{~kg}$. With the burning of $1 \mathrm{~kg}$ of $30 \%$ sunflower shells and $70 \%$ lignite composition, the highest $\mathrm{CO}_{2}$ emission with $2.648 \mathrm{~kg}$ occurs in Kütahya-Ömerler (washed) and the lowest in Muğla-Eskihisar lignite with $2.346 \mathrm{~kg}$. The highest $\mathrm{SO}_{2}$ emission occurs in Kütahya Seyitömer-Ayvalı with 0.044 $\mathrm{kg}$, while the lowest in Manisa Kisrakdere lignite with 
$0.012 \mathrm{~kg}$. The highest $\mathrm{H}_{2} \mathrm{O}$ emission occurs in Manisa Kısrakdere lignite with $0.490 \mathrm{~kg}$, Kütahya SeyitömerAyvalı with the lowest $0.400 \mathrm{~kg}$. By burning $1 \mathrm{~kg}$ of $50 \%$ sunflower shells and 50\% lignite composition, the highest $\mathrm{CO}_{2}$ emission with $2.399 \mathrm{~kg}$ occurs in Kütahya-Ömerler (washed) and the lowest in Muğla-Eskihisar lignite with $2.184 \mathrm{~kg}$. The highest $\mathrm{SO}_{2}$ emission occurs in Kütahya Seyitömer-Ayvalı with $0.030 \mathrm{~kg}$, while the lowest in Manisa Kisrakdere lignite with $0.009 \mathrm{~kg}$. The highest $\mathrm{H}_{2} \mathrm{O}$ emission occurs in Manisa Kisrakdere lignite with 0.492 $\mathrm{kg}$ and Kütahya Seyitömer-Ayvalı with the lowest 0.432 $\mathrm{kg}$.

With the burning of $1 \mathrm{~kg}$ of $10 \%$ olive cake and $90 \%$ lignite composition, the highest $\mathrm{CO}_{2}$ emission with 2.937 $\mathrm{kg}$ occurs in Kütahya-Ömerler (washed) and the lowest in Muğla-Eskihisar lignite with $2.548 \mathrm{~kg}$. The highest $\mathrm{SO}_{2}$ emission occurs in Kütahya Seyitömer-Ayvalı with 0.061 $\mathrm{kg}$, while the lowest in Manisa Kisrakdere lignite with $0.016 \mathrm{~kg}$. The highest $\mathrm{H}_{2} \mathrm{O}$ emission is $0.494 \mathrm{~kg}$ in Manisa Kısrakdere lignite and Kütahya Seyitömer-Ayvalı with the lowest $0.370 \mathrm{~kg}$. With the burning of $1 \mathrm{~kg}$ of $30 \%$ olive cake and $70 \%$ lignite composition, the highest $\mathrm{CO}_{2}$ emission with $2.701 \mathrm{~kg}$ occurs in Kütahya-Ömerler (washed) and the lowest in Muğla-Eskihisar lignite with $2.398 \mathrm{~kg}$. The highest $\mathrm{SO}_{2}$ emission occurs in Kütahya Seyitömer-Ayvalı with $0.045 \mathrm{~kg}$, while the lowest in Manisa K1srakdere lignite with $0.013 \mathrm{~kg}$. The highest $\mathrm{H}_{2} \mathrm{O}$ emission is $0.507 \mathrm{~kg}$ in Manisa Kisrakdere lignite and Kütahya Seyitömer-Ayvalı with the lowest $0.418 \mathrm{~kg}$. By burning $1 \mathrm{~kg}$ of $50 \%$ olive cake and $50 \%$ lignite composition, the highest $\mathrm{CO}_{2}$ emission with $2.479 \mathrm{~kg}$ occurs in Kütahya-Ömerler (washed), and the lowest in Muğla-Eskihisar lignite with $2.263 \mathrm{~kg}$. The highest $\mathrm{SO}_{2}$ emission occurs in Kütahya Seyitömer-Ayvalı with 0.031 $\mathrm{kg}$, while the lowest in Manisa Kisrakdere lignite with $0.010 \mathrm{~kg}$. The highest $\mathrm{H}_{2} \mathrm{O}$ emission occurs in Manisa Kisrakdere lignite with a maximum of $0.519 \mathrm{~kg}$ and in Kütahya Seyitömer-Ayvalı lignite with a minimum of $0.460 \mathrm{~kg}$.

By burning $1 \mathrm{~kg}$ of $10 \%$ woodchips and $90 \%$ lignite composition, the highest $\mathrm{CO}_{2}$ emission with $2.938 \mathrm{~kg}$ occurs in Kütahya-Ömerler (washed) and the lowest in Muğla-Eskihisar lignite with $2.549 \mathrm{~kg}$. The highest $\mathrm{SO}_{2}$ emission occurs in Kütahya Seyitömer-Ayvalı with 0.061 $\mathrm{kg}$, while the lowest in Manisa Kisrakdere lignite with $0.016 \mathrm{~kg}$. The highest $\mathrm{H}_{2} \mathrm{O}$ emission is $0.504 \mathrm{~kg}$ in Manisa Kısrakdere lignite and Kütahya Seyitömer-Ayvalı with the lowest $0.382 \mathrm{~kg}$. With the burning of $1 \mathrm{~kg}$ of $30 \%$ woodchips and $70 \%$ lignite composition, the highest $\mathrm{CO}_{2}$ emission with $2.702 \mathrm{~kg}$ occurs in Kütahya-Ömerler (washed) and the lowest in Muğla-Eskihisar lignite with $2.402 \mathrm{~kg}$. The highest $\mathrm{SO}_{2}$ emission occurs in Kütahya Seyitömer-Ayvalı with $0.044 \mathrm{~kg}$, while the lowest in Manisa K1srakdere lignite with $0.012 \mathrm{~kg}$. The highest $\mathrm{H}_{2} \mathrm{O}$ emission is $0.534 \mathrm{~kg}$ in Manisa K1srakdere lignite and Kütahya Seyitömer-Ayvalı with the lowest $0.450 \mathrm{~kg}$. With the burning of $1 \mathrm{~kg}$ of $50 \%$ woodchips and $50 \%$ lignite composition, the highest $\mathrm{CO}_{2}$ emission with 2.483 $\mathrm{kg}$ occurs in Kütahya-Ömerler (washed) and the lowest in Muğla-Eskihisar lignite with $2.271 \mathrm{~kg}$. The highest $\mathrm{SO}_{2}$ emission occurs in Kütahya Seyitömer-Ayvalı with 0.029 $\mathrm{kg}$, while the lowest in Manisa Kisrakdere lignite with
$0.009 \mathrm{~kg}$. The highest $\mathrm{H}_{2} \mathrm{O}$ emission occurs in Manisa Kisrakdere lignite with the highest $0.563 \mathrm{~kg}$ and lowest $0.509 \mathrm{~kg}$ in Kütahya Seyitömer-Ayvalı lignite.

The most important chemical elements in terms of fuel properties and emissions are carbon, hydrogen, oxygen and sulfur. The carbon percentage in 10 different lignites selected is over $50 \%$. Kütahya Tunçbilek lignite has the highest carbon rate. The carbon ratio of this lignite is $70.58 \%$. The lowest is Kütahya Seyitömer-Ayvalı lignite. Its carbon ratio is $53.70 \%$. The highest hydrogen rate is $4.74 \%$ in Bursa Orhaneli lignite. The lowest is $2.74 \%$ of lignite extracted from Kütahya Seyitömer-Ayvalı. The highest oxygen content is $15.03 \%$ of lignite extracted from Muğla Eskihisar. The lowest is $5.48 \%$ of the lignite mined by Kütahya Ömerler. The highest sulfur content is Kütahya Seyitömer (washed) lignite and it is $2.55 \%$. The highest is Manisa Kisrakdere lignite and its ratio is $0.79 \%$.

Woodchips have the highest carbon ratio among agricultural wastes selected as Biomass with $53.7 \%$. The lowest is corn cobs with $47.8 \%$. The highest hydrogen content is woodchips with $6.9 \%$, while the lowest is $5.5 \%$ sunflower shells. The highest oxygen rate is $45.6 \%$ with corn cobs and the lowest is olive cake with $36.9 \%$. The highest sulfur rate is Walnut shells with $0.09 \%$, while the agricultural waste that does not contain any sulfur is woodchips.

\section{Conclusions}

As a result, the highest $\mathrm{CO}_{2}$ emission was obtained in Kütahya-Ömerler (Washed) and the lowest in MuğlaEskihisar lignite by burning $1 \mathrm{~kg}$ of fuel mixture in a fluidized bed combustion system obtained by combining all types of lignite and all biomass agricultural wastes in certain proportions,. The highest $\mathrm{SO}_{2}$ emission was obtained in Kütahya-seyitömer-Ayvalı region lignite and the lowest in Manisa-Kisrakdere lignites. $\mathrm{H}_{2} \mathrm{O}$ emission was obtained in Manisa-Kısrakdere lignite and lowest in Kütahya Seyitömer-Ayvalı lignite.

The determinant of $\mathrm{CO}_{2}$ and $\mathrm{SO}_{2}$ emissions in all of the fuel mixtures obtained by combining different types of lignite and agricultural wastes in certain proportions is the carbon and sulfur ratios in the lignite used. Lignite, which has the highest carbon and sulfur ratio, is decisive in the $\mathrm{CO}_{2}$ and $\mathrm{SO}_{2}$ emissions in the new fuel mixture. The decisive factor in $\mathrm{H}_{2} \mathrm{O}$ emission is the hydrogen ratio in agricultural wastes. In the mixture of lignite and agricultural waste with the highest hydrogen ratio, $\mathrm{H}_{2} \mathrm{O}$ emission occurs in the highest amount.

As the biomass rate increases, while $\mathrm{CO}_{2}$ and $\mathrm{SO}_{2}$ emissions decrease, $\mathrm{H}_{2} \mathrm{O}$ emissions increase. This is because, according to Biomass, while the carbon ratio and sulfur ratio in lignite is higher, the hydrogen ratio is less. Since the hydrogen rate in biomass is higher than lignite, the higher the biomass rate, the more $\mathrm{H}_{2} \mathrm{O}$ is obtained as a result of the burning event. On the other hand, less $\mathrm{CO}_{2}$ and $\mathrm{SO}_{2}$ emissions occur.

For the \%10 biomass - \%90 lignite mixtures, by burning of $1 \mathrm{~kg}$ lignite and biomass mixture, the highest $\mathrm{CO}_{2}$ emission occurs from $10 \%$ woodchips - $90 \%$ Kütahya - Ömerler (washed) as $2.938 \mathrm{~kg}$ and the highest 
$\mathrm{SO}_{2}$ emission obtained from $10 \%$ olive cake - $90 \%$ Kütahya Seyitömer-Ayvalı lignite mixture as $0.061 \mathrm{~kg}$. The highest $\mathrm{H}_{2} \mathrm{O}$ emission is obtained by mixing $10 \%$ woodchips - 90\% Manisa-Kısrakdere lignite as $0.504 \mathrm{~kg}$.

For the $\% 30$ biomass - \% 70 lignite mixtures, with the burning of $1 \mathrm{~kg}$ lignite and biomass mixture, the highest $\mathrm{CO}_{2}$ emission occurs from 30\% woodchips - $70 \%$ Kütahya - Ömerler (washed) as $2.702 \mathrm{~kg}$ and the highest $\mathrm{SO}_{2}$ emission obtained from $30 \%$ olive cake $-70 \%$ in Kütahya Seyitömer-Ayvalı lignite mixture as $0.045 \mathrm{~kg}$. The highest $\mathrm{H}_{2} \mathrm{O}$ emission is obtained by mixing $30 \%$ woodchips - 70\% Manisa-Kisrakdere lignite as $0.534 \mathrm{~kg}$.

For the $\% 50$ biomass - \%50 lignite mixtures, when 1 $\mathrm{kg}$ lignite and biomass mixture is burned, the highest $\mathrm{CO}_{2}$ emission occurs from 50\% woodchips - 50\% Kütahya Ömerler (washed) with $2.483 \mathrm{~kg}$ and the highest $\mathrm{SO}_{2}$ emission obtained from $50 \%$ olive cake - $50 \%$ in Kütahya Seyitömer-Ayvalı lignite mixture as $0.031 \mathrm{~kg}$. The highest $\mathrm{H}_{2} \mathrm{O}$ emission is obtained by mixing $50 \%$ woodchips $-50 \%$ Manisa-Kısrakdere lignite as $0.563 \mathrm{~kg}$.

In the literature, the combustion properties of new fuels which limited number formed by the mixture of different lignite types and agricultural wastes are examined. In this study, agricultural wastes and lignites located in Turkey, emissions by burning new fuels that great number formed by mixing in different proportions is examined. Thus, it was possible to compare new fuels. Accordingly, the better mixing ratio and fuel type can be determined. In later studies, the combustion properties and emission amounts of the fuels that will be formed by mixing different types of biomass such as garbage waste, waste paper, grape waste and sewage sludge with lignite will be investigated.

\section{Reference}

1. A. Elorf, B. Sarh, Excess air ratio effects on flow and combustion caracteristics of pulverized biomass (olive cake), Case Stud. Therm. Eng. 13 (2019)

2. D. Kopuz, Investigation the combustion behaviour of coal-biomass blends, Chemical Engineering Department, Istanbul Technical University, Master Thesis, Turkey, (2011)

3. B. Engin, H. Atakül, A. Ünlü, Z. Olgun, CFB combustion of low-grade lignites: Operating stability and emissions, J. Energy Inst. 92 (2019)

4. L. Armestoa, A. Bahillo, A. Cabanillas, K. Veijonen, J. Otero, A. Plumed, L. Salvador, Co-combustion of coal and olive oil industry residues in fluidised bed, Fuel 82 (2003)

5. W. K. Kordylewski, K. J. Mościcki, K. J. Witkowski, Lab-Scale investigations during combustion of agricultural residues and selected polish coals, Chem. Process Eng. 35, 2 (2014)

6. T. Madhiyanon, P. Sathitruangsak, S. Soponronnarit, Co-combustion of rice husk with coal in a cyclonic fluidized-bed combustor ( $\Psi-F B C)$, Fuel 88 (2009)

7. A. T. Atimtay, M. Varol, Investigation of cocombustion of coal and olive cake in a bubbling fluidized bed with secondary air injection, Fuel $\mathbf{8 8}$ (2009)

8. S. V. Vassilev, D. Baxter, C. G. Vassileva, An overview of the behaviour of biomass during combustion: Part I. Phase-mineral transformations of organic and inorganic matter, Fuel 112 (2013)

9. M. Varol, A. T. Atimtay, H. Olgun, H. Atakül, Emission characteristics of co-combustion of a low calorie and high sulfur-lignite coal and woodchips in a circulating fluidized bed combustor: Part 1. Effect of excess air ratio, Fuel 117 (2014)

10. M. A. Bennini, A. Koukouch, I. Bakhattar, M. Asbik, T. Boushaki, B. Sarh, A. Elorf, B. Cagnon, S. Bonnamy, Characterization and Combustion of Olive Pomace in a Fixed Bed Boiler: Effects of Particle Sizes, Int. J. Heat Technol. 37, 1 (2019)

11. A. A. Bhuiyan, J. Naser, CFD modelling of co-firing of biomass with coal under oxy-fuel combustion in a large scale power plant, Fuel 159 (2015)

12. A. Pimchuai, A. Dutta, P. Basu, Torrefaction of agriculture residue to enhance combustible properties, Energ Fuel 24 (2010)

13. D. Vamvuka, S. Saxioni, Investigation of slagging/fouling and environmental impact of ashes produced from co-combustion of urban wastes with lignite, Fresen. Environ. Bull. 21, 11 (2012)

14. W. Jerzak, Z. Kalicka, E. Kawecka-Cebula, R. Straka, Retention of $\mathrm{S}$ with lignite using cedarnut shell in the co-combustion process performed in a fluidized bed combustor, Combust. Sci. Technol. 190, 4 (2018)

15. A. Elorf, N-M. Koched, T. Boushaki, B. Sarh, J. Chaoufi, S. Bostyn, I. Gökalp, Swirl motion effects on flame dynamic of pulverized olive cake in a vertical furnace, Combust. Sci. Technol 188, 11-12 (2016)

16. N. Vardar, N. İlten, Pirina yakilmasi neticesinde oluşan baca gazi emisyonlari ve sonuçlarin değerlendirilmesi, Ulusal Yanma ve Hava Kirliliği Kontrolu Sempozyumu VI, İzmir/Türkiye (2003)

17. W. Jerzak, Z. Kalicka, E. Kawecka-Cebula, Cocombustion of biomass and bituminous coal in a fluidized two-bed reactor, Energ. Source Part A 396 (2017)

18. Y. Çengel, M. A. Boles, Mühendislik Yaklaşımı ile Termodinamik, McGraw-Hill, Literatür yayıncılık, (Çeviri Dertbentli, T.) (1996)

19. K. Çomaklı, B. Yüksel, Environmental impact of thermal insulation thickness in buildings. Appl. Therm. Eng. 24 5-6 (2004). 